\title{
The potential of biofilms from moving bed bioreactors to increase the efficiency of textile industry wastewater treatment
}

\section{REZUMAT - ABSTRACT}

\section{Potențialul biofilmelor din bazinele cu biofilm fixat pe suport artificial mobil în creșterea eficienței de epurare}

a apelor uzate generate de către industria textilă

Procesele din industria textilă produc unele dintre cele mai poluate ape reziduale din lume. Apele reziduale din industria textilă sunt, de asemenea, foarte variabile (variază în funcție de timp și de fabrică) și conțin o mare varietate de poluanți. Acest lucru face ca tratamentul efluenților din industria textilă să fie complex, specific și scump. Numeroase combinații de tehnologii de tratare a apelor reziduale sunt aplicate în prezent în industria textilă, însă metodele care funcționează sunt adesea necorespunzătoare, insuficiente, necorespunzătoare sau nesustenabile. Odată cu evoluția industriei textile, cercetarea din domeniul epurării apelor reziduale trebuie să țină pasul cu cerințe care sunt în continuă creștere. Obiectivul mai extins al epurării apelor reziduale din industria textilă este maximizarea eficienței eliminării poluanților, în timp ce se eliberează efluenți pe care societatea îi consideră acceptabili și siguri din punct de vedere ecologic. În ultimii zece ani s-au făcut mari eforturi pentru a reduce consumul biochimic de oxigen $\left(\mathrm{CBO}_{5}\right)$ și amoniac $(\mathrm{NH} 4+)$ în apele reziduale. Aceste progrese conduc la întrebarea: intensificarea utilizării acestor tehnologii din industria textilă poate să ducă la creșterea eficienței sale? Echipa de cercetare a analizat epurarea apei prin biomineralizare aerobă prin intermediul biofilmelor microbiene imobilizate pe suprafețe solide și situate în reactoare cu biofilm fixat pe suport artificial mobil (MBBRs). Aceste biofilme sunt selectate pentru oxidarea carbonului și amoniacului. Autorii compară potențialul de biotratare cu nămol activ cu performanța bioreactorului de tip MBBR. Rezultatele sunt utilizate pentru a evalua potențialul MBBR ca soluție de reducere a costurilor în instalațiile de epurare a apelor reziduale din industria textilă. Analiza susține că modernizarea unor astfel de stații cu o utilizare mai intensă a biotehnologiei MBBR ar crește sustenabilitatea și atitudinea prietenoasă față de mediu. Autorii abordează, de asemenea, direcțiile de cercetare și reperele pentru extinderea efectelor MBBR asupra tratării apelor reziduale din industria textilă.

Cuvinte-cheie: biofilme, tratarea apelor reziduale, $\mathrm{CBO}_{5}$, amoniac, industria textilă

The potential of biofilms from moving bed bioreactors to increase the efficiency of textile industry wastewater treatment

Textile industry processes produce some of the most heavily polluted wastewater worldwide. Wastewater from textile industry is also highly variable (it varies with time and among factories) and contains wide diversity of pollutants. This makes the treatment of textile industry effluents, complex, site-specific and expensive. Numerous combinations of wastewater treatment technologies are currently applied in the textile industry, yet methods that work for one emitter are often unsuitable, insufficient, not necessary or unsustainable to another. As textile industry evolves, its water treatment research also has to keep pace with increasing demands. The broader aim of the textile industry wastewater treatment is to maximize the efficiency of pollutant removal, while releasing effluents that society considers as being environmentally acceptable or safe. In the last ten years great strides have been made in the ability to lower the biological oxygen demand $(B O D)$ and ammonium (NH4+) in wastewater. These advances elicit the question: can intensifying the usage of such technologies in the textile industry also increase its efficiency? The research team analysed water treatment by aerobic biomineralization via microbial biofilms immobilized on solid surfaces and hosted in Moving Bed Bio-Reactors (MBBRs). These biofilms are selected for carbon oxidation and ammonia oxidation. The authors compare the potential of active sludge biotreatment with the performance of MBBRs. The results are used to evaluate the potential of MBBRs as a cost-reducing solution in textile wastewater treatment plants. Our analysis supports that upgrading such stations to more heavily usage of MBBR biotechnology would increase their sustainability and environmental friendliness. The authors also discuss research directions and milestones for expanding the effects of MBBRs on the textile industry wastewater treatment.

Keywords: biofilms, wastewater treatment, $B O D$, ammonia, textile industry

\section{INTRODUCTION}

The textile industry is one of the largest water polluter worldwide in terms of the number of chemicals produced, in the amount of chemicals released and in the amount of wastewater produced [1]. This industry generates approximately 70 billion tons of wastewater each year [2]. Waste water produced by this industry is too toxic to be released in nature, and has to be treated. As water treatment plants that are commonly used to treat domestic water waste cannot handle textile industry outflows, textile industry factories use custom made water treatment stations. 
The various processes used by the textile industry (staining, printing, bleaching, scouring, defatting, hydrolysis, etc.) produce dissimilar types of pollution. These waste streams vary greatly with regards to the chemicals they contain and their concentration, but may also vary considerably in time even for the same factory. Legislation regarding what is, and what is not, allowed to be discarded in nature by the textile industry varies from one country to another. In this paper are presented the legal limits from three textile industry producers: Germany, China and Romania.

Wastewater treatment plants (WWTP) used in the textile industry are complex and in most cases custom-designed for specific emitters and chemicals. The most important criteria for judging these stations are: chemical specificity, efficiency at removing pollutants and cost. Water treatment technologies have to keep pace with a fast-evolving textile industry (in terms of materials and methods). Fast response in water treatment technologies is the key to balance legal pollutant requirements with the economical sustainability of the textile industry.

The most frequent and abundant pollutants produced by the textile industry include (in no specific order): dyes, sulfide, enzymes, starch, ammonia, aniline, organic carbon, disinfectants, insecticides, $\mathrm{NaOH}$, surfactants, fats, waxes, enzymes, peroxide, metals, salts, solvents, chlorinated compounds, acetate, softeners, urea and formaldehyde. In this paper we focus on advances in the removal of ammonia nitrogen $\left(\mathrm{NH}_{4}{ }^{+}-\mathrm{N}\right)$ and the fraction of organic carbon that can be lowered by aerobic respiration and called Biological Oxygen Demand (BOD). These choices $\left(\mathrm{NH}_{4}{ }^{+}-\mathrm{N}\right.$ and $\left.\mathrm{BOD}\right)$ came from increasing pressure from the public and from legislation to control emissions that can produce eutrophic pollution or anoxia in ecosystems.

\section{MBBR UTILIZATION FOR THE TREATMENT OF THE TEXTILE WASTEWATERS}

\section{Biofilm carriers}

The Moving Bed Biofilm Reactor (MBBR) process is based on the aerobic biofilm principle and has the advantages of activated sludge and other biofilm systems and in the same time exceeds the disadvantages of activated sludge processes. The biofilm carriers are made from varied materials, but most of them are mare from high density polyethylene or varied materials mixtures based on polyethylene. The materials for the realization of biomedia are selected based on several criteria such as: porosity, erosion resistance, size and density (the biofilm carriers must have a close-to-water density). Using a relatively small reactor volume can maintain a high biological activity by utilizing biofilm carriers with a large specific surface area $\left(\mathrm{m}^{2} / \mathrm{m}^{3}\right)$. The biofilm carriers are mixed inside the wastewater tanks with the help of bubbles produced by the diffusers of the aeration system. This type of free biomedia is the most efficient since the clogging is not possible.
There are several models of biofilm carriers worldwide and a few of these are shown in figure 1 [3, 4].

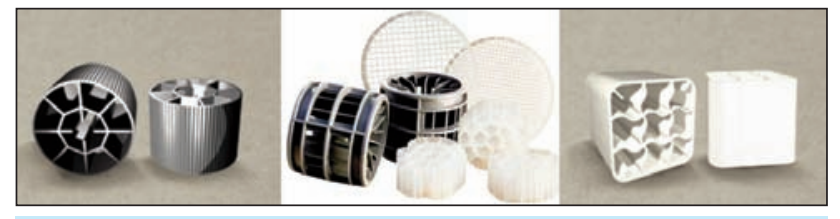

Fig. 1. Biofilm carriers [3, 4]

As shown in figure 1 and figure 2, the biofilm carriers have an internal zone, where the biofilm is created and protected. These internal surfaces provide protected areas and optimal conditions for the bacteria culture to thrive and develop. The biofilm inside each carrier element protects the bacterial cultures against the industrial processes with fluctuations in pollutants' discharging. The free carriers represent a stable place for the microorganisms to grow, compared to the activated sludge process, so less tank volume is needed. Essentially nutrient and dissolved oxygen levels are the only control aspects for the process operation. MBBRs are used to remove biological and chemical oxygen demand (BOD and COD) from wastewater streams. Nitrogen removal is also efficient in MBBRs. Existing activated sludge wastewater treatment plants can be upgraded using biofilm caries, to achieve higher efficiencies for COD, BOD, nitrogen and phosphorus removal. The MBBR technology provided satisfaction to thousands of both municipal and industrial beneficiaries worldwide.

A new type of biofilm carrier was developed, which evolved from the existing models using the Kaldness process and were modified to obtain a higher strength and a larger surface for biofilm development. In figure 2 is presented the new type of biofilm carrier, developed by some of the authors.

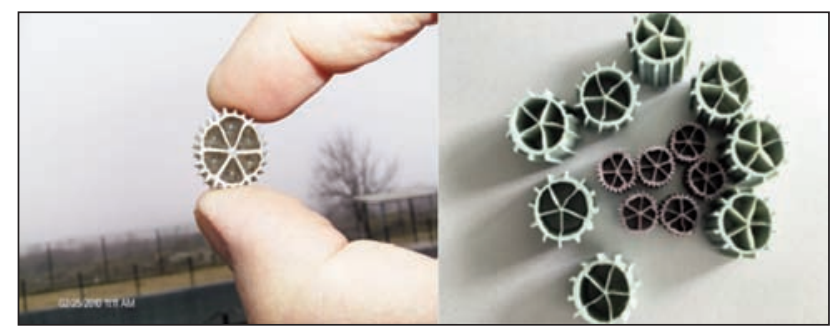

Fig. 2. Biofilm carriers

\section{Biofilms development and utilization in process engineering}

Biofilms are assemblages of microorganisms, encased in a matrix, that function as a cooperative consortium, the biofilm mode of life being a feature common to most microorganisms in natural, medical and engineered systems including those involved in wastewater treatment [5]. Many bacteria can adhere non-specifically to different surfaces but some bacteria adhere best to hydrophobic substrates whereas other 
adhere best to hydrophilic substrates [6] or to intermediate materials [7-8]. Interesting, the growing conditions influence the ability of the same bacterium. The chemical nature of the biomedia (biofilm carriers) to be used in a waste water treatment plants should be carefully chosen to promote biofilm formation and activity.

According to Costerton, in the last decade it became clear that bacteria live preferentially in multicellular biofilms in which cells established optimal metabolic interaction for their persistence in the ecosystem [9]. These biofilm communities have developed structures and strategies in response to attacks by chemical and biological antagonists, as well as for the availability of nutrients. The predominance of biofilms in natural and engineered ecosystems is of paramount importance for the processes occurring in those ecosystems, and for understanding them. Chronologically, biofilms were first observed in oligotrophic mountain streams and afterwards in natural aquatic systems of increasing nutrient content, culminating in abattoir effluents, deeply questioning about the biological significance of biofilms. Nowadays it is generally accepted that the bulk of bacterial transformations that occur in the biosphere take place in these sessile microbial communities, which are also important in engineered ecosystems.

The followings are the advantages of bacterial life in biofilms [6, 10]:

a) Increased nutrient availability, as compared with free, planctonic way of life, the chemicals, including macromolecules, being subject of adsorption at different (clean) surfaces immersed into a natural or engineered ecosystem. This process is obvious especially in environments where the nutrient concentrations are very low (open ocean, mountain lakes etc.). b) The biological diversity of biofilms occurring in natural and engineered ecosystems favors very complex interactions between individual cells, including complex catabolic and anabolic reactions, based on complementary nutritional and physiological associations between bacteria, thus enabling the biofilm with improved capabilities. This aspect is essential for biofilms active in different type of wastewater plants. c) The dense structure of biofilm and close physical contact between individual cells promote increased genetic exchanges between cells as well as cell-cell signalling processes, called quorum sensing.

d) Protection from harmful factors such as antibiotics, chlorine (disinfectants, in general) and heavy metals, the increased resistance being based on extra parietal structures of bacteria and complex inter-cellular matrix of biofilm, as well as to mechanism(s) occurring at individual level. There is evidence that bacteria, especially those bellow the biofilm-water interface, more closely to the solid substrate, are protected against grazing by protozoa and metazoa, parasitism by bacteriophages or by bacteria, (e.g. Bdellovibrio), as well as from predation by amobe. The followings are the disadvantages of bacterial life in biofilms [6]: a) As they are fixed (at a given scale time) in biofilm bacteria seems to be more exposed to grazing as compared with free, planctonic bacteria or actively (e.g. flagella etc.) moving bacteria.

b) Due to the complex structure and dimensions of biofilms (thickness from micrometers to millimeters or more) different type of gradients occur. Aerobic microorganisms occur at the biofilm-water interface consuming the molecular oxygen which, at deeper position in the biofilm, become absent, thus creating conditions for anaerobic bacteria, capable of either anaerobic respiration (on nitrate, for example, if present) or fermentation.

For the point of view of the usefulness of biofilms in MBBR, all the above aspects are important, but new points could emerge. For example, grazing by protozoa and metazoa could be useful as the external cells are removed, the remaining cells being closer to the surface; this situation favors an improved exchange of chemicals with the liquid phase, thus maintaining the cells in an active state of growth.

Thus, biological and technical parameters should be optimized together for a robust and efficient biofilm activity in MBBR.

The complex physical structure of the biofilms as well as their biological diversity with respect to strains living there, their metabolism and metabolic interactions, based on a huge genetic diversity make them robust ecosystems. This is why different types of solid materials are added to bioreactors in order to provide attachment surfaces for the biofilm development, with positive effects both on the increase of active biomass and higher rates of pollutants degradation [11]. The advantages of biofilms in different type of wastewater plants configurations are further enhanced by the specific configuration of MBBR, where the biofilm concentration per volume unit is higher compared to the classical biological wastewater treatment. There is the need to monitor the quantity of the cells within the biofilms as well as their metabolic activity [5, 12-13].

The research team focused on few usual methods. The quantity of cells within the biofilms is usually measured by crystal violet assay, a method which do not differentiate between alive cells, active cells or dead cells [13]. However, the method has the advantage that is rapid and cheap, being also widespread in the study of different types of biofilms, not only those important in wastewater treatment. One method to differentiate alive cells from dead cells uses two types of fluorescent markers - one which is impermeable to normal, healthy plasma membrane (e.g. propidium homodimer) and the other one which is permeable to both normal and severely injured plasma membranes (related to dead cells or dying cells, ex. Syber green) [13]. Dead cells are labelled by both markers whereas the living cells are labelled only by Syber green. However, these fluorescent markers can be used with ordinary fluorescent microscopes only for incipient states of biofilm development, where the biofilm is composed of only one 
layer of cells (mono-stratified). The life span of biofilm is composed mainly of multilayered bioflm, where is the need to use confocal microscopes [13]. When it comes to metabolic activity (and, indirectly, the amount of living cells) the use of resazurine method reach some popularity [14-18]

In figure 3, it is presented the same microscopic filed inspected in either green filter (Syber green fluorescence) or red filter (bromide homodimer I fluorescence), containing cells form disintegrated (ultrasonic treatment in the presence of Tween 20) biofilm from the biofilm carriers developed by the research team and presented in figure 2. Total cells (both alive and dead) are labelled by SG whereas the dead cells are labelled only by HD- the difference consists of alive cells.

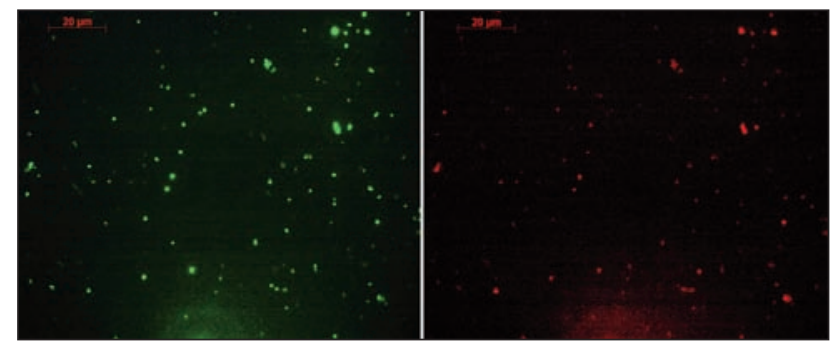

Fig. 3. Fluorescence images of the same microscopic field containing cells chemically detached from the new biomedia: total cell (both alive and dead) were labelled with Syber Green I (green fluorescence) whereas dead cells were labelled with Bromide Homodimer I (red fluorescence)

\section{NUMERICAL SIMULATIONS FOR MBBR}

\section{DESIGNING DESIGN AND FUNCTION OF MBBRS}

Since a considerable number of parameters is interfering with the treatment efficiency in MBBRs (as shown above), further researches are necessary to design a proper biological treatment stage. For the breathing process of the micro-organisms capable to reduce $\mathrm{BOD}$ and $\mathrm{NH}_{4}{ }^{+}-\mathrm{N}$ inside the biological tanks, an aeration system is needed. The needed dissolved

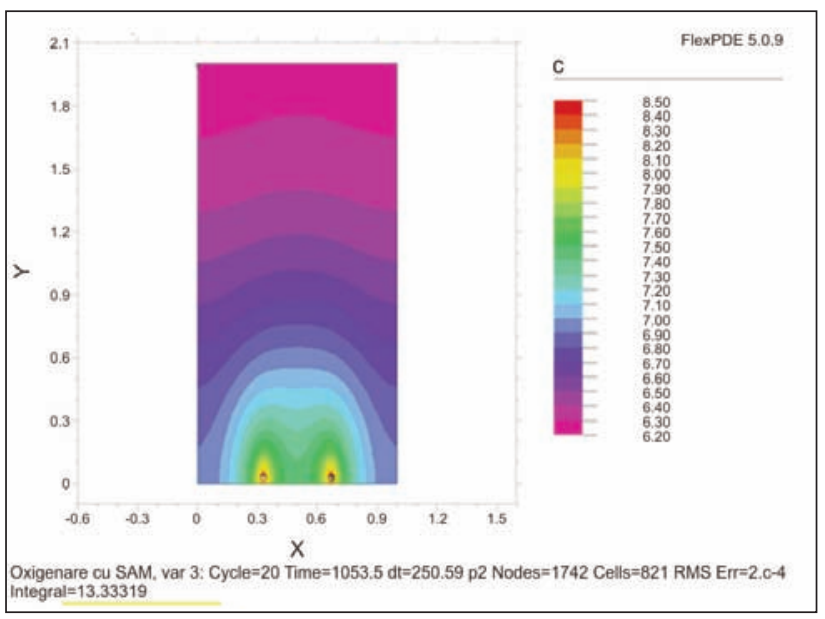

Fig. 4. Dissolved oxygen concentration profiles - cross section oxygen (DO) quantity is established both from numerical determination. However, with the help of the numerical simulation the DO quantity inside MBBR can be known. The scientific literature states that an important advantage of MBBR utilization instead of activated sludge is the fact that lass energy is required [1]. Using numerical simulations, the research team also demonstrated the above statement. MBBRs use less electrical energy than activated sludge process since less air (DO) is needed inside the tanks. The biofilm carriers act as a barrier in front of the air bubbles, thus increasing the retention time.

The research team realized a serial of numerical simulation to determine the DO profiles inside a MBBR. The dispersion equation was considered to realize the mathematical model for the determination of the DO profile inside a MBBR [1]:

$$
\begin{gathered}
\frac{\partial \bar{C}}{\partial t}+\frac{\partial}{\partial x}(\bar{u} \bar{C})+\frac{\partial}{\partial y}(\bar{v} \bar{C})+\frac{\partial}{\partial z}(\bar{w} \bar{C})= \\
=\frac{\partial}{\partial x}\left(\varepsilon_{x} \frac{\partial \bar{C}}{\partial x}\right)+\frac{\partial}{\partial y}\left(\varepsilon_{y} \frac{\partial \bar{C}}{\partial y}\right)+\frac{\partial}{\partial z}\left(\varepsilon_{z} \frac{\partial \bar{C}}{\partial z}\right)+ \\
+D_{m}\left(\frac{\partial^{2} \bar{C}}{\partial x^{2}}+\frac{\partial^{2} \bar{C}}{\partial y^{2}}+\frac{\partial^{2} \bar{C}}{\partial z^{2}}\right)+S(x, y, z, t)
\end{gathered}
$$

where $\varepsilon_{x}, \varepsilon_{y}, \varepsilon_{z}$ are the longitudinal, transversal and vertical dispersion coefficients. Due to the dependence of dispersion coefficients to the flow regime, the simplified form of the above equation was considered:

$$
\frac{\partial \bar{C}}{\partial t}+\frac{\partial}{\partial x}(\bar{u} \bar{C})+\frac{\partial}{\partial y}(\bar{v} \bar{C})=\frac{\partial}{\partial x}\left(\varepsilon_{x} \frac{\partial \bar{C}}{\partial x}\right)+\frac{\partial}{\partial y}\left(\varepsilon_{y} \frac{\partial \bar{C}}{\partial y}\right)
$$

where quantities are averaged over a time period. In figures 4-7 are presented the results obtained from numerical simulations. There were considered several cases: cross section through the bioreactor without and with biofilm carriers in different proportions.

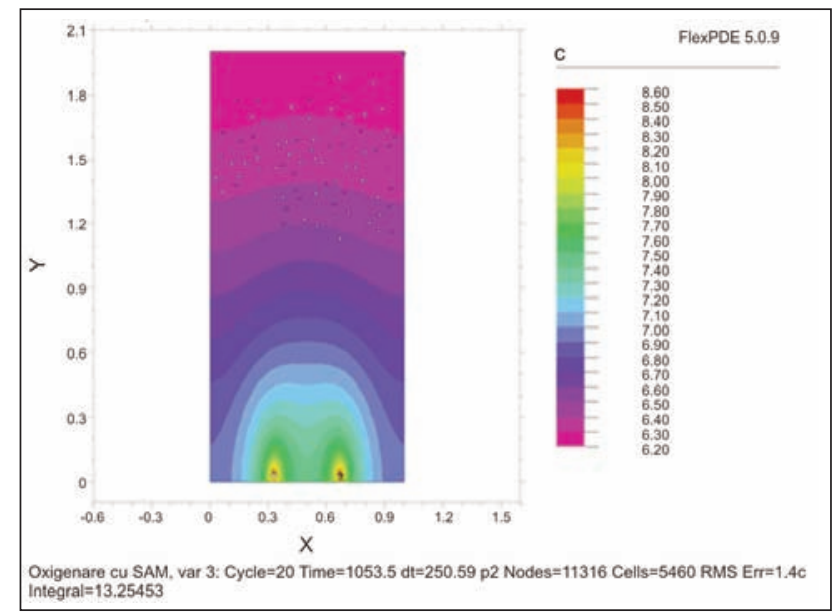

Fig. 5. Dissolved oxygen concentration profiles - cross section 


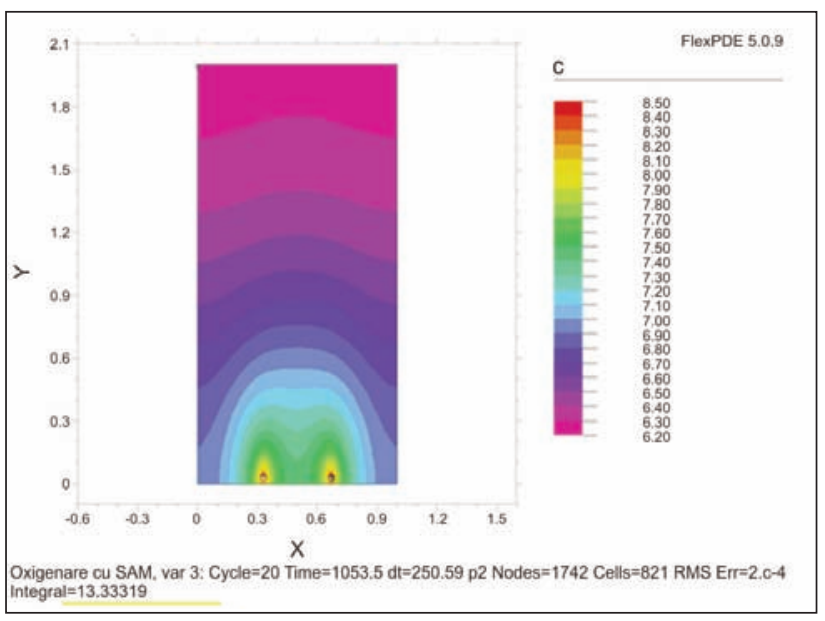

Fig. 6. Dissolved oxygen concentration profiles - cross section

Analysing figures $4-7$ it can be easily observed the fact that biofilm carriers help the oxygenation process, resulting air bubbles which rise to the surface meeting in their way the biofilm carriers. Bubbles, due to their interactions with the media, divide and by-pass the biofilm carriers. The contact duration between air and wastewater increases, resulting a better oxygen mass transfer. Also, the increasing quantity of the biofilm carrier inside a MBBR reactor leads to a better mass transfer. In this way, it is necessary to introduce a smaller amount of air which implies a reduced energy consumption.

\section{RESULTS AND DISCUSIONS}

\section{Pollutants in textile chemistry wastewater}

The textile wastewaters are especially characterized by the presence of dyes. In dyeing, color is applied in the form of solutions and the dye is applied as a thick layer of paste. Also, in the textile dyeing industry, bleaching is an important process and it needs almost $35 \%$ of the total water consumed in textiles wet processes. Bleaching it is based on: sodium hypochlorite, hydrogen peroxide and sodium chlorite. The pollutants generated by dyeing and bleaching are important and they lead to a high COD (chemical oxygen demand), TSS (total suspended solids), chlorine etc. High values of $C O D$ and $\mathrm{BOD}_{5}$, TSS, oil and grease in the effluent causes depletion of DO, which has an adverse effect on the environment. The potential specific pollutants from textile printing and dyeing are presented in table 1 [20].

\section{Limits for textile industry discharge}

The dyeing wastewaters have many complex components with high concentrations of pollutants. According to the high values for BOD and COD, coloration, salt etc. the wastewaters resulting from dyeing cotton with reactive dyes are seriously polluted. The characteristics of discharged wastewaters vary and depend on the type of textile manufactured and the dyes/chemicals used. The effluents contain considerable amounts of agents, including suspended and dissolved solids, BOD, COD, chemicals, odor

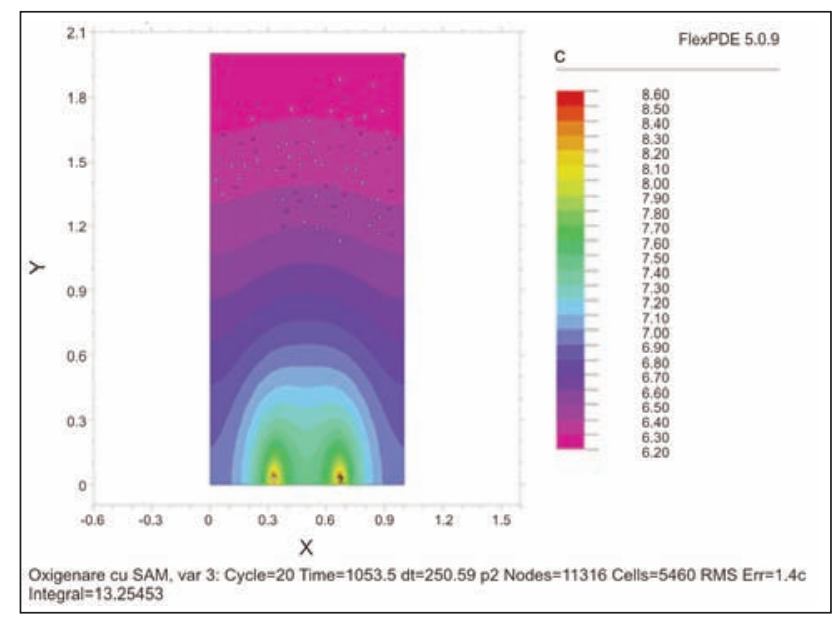

Fig. 7. Dissolved oxygen concentration profiles - cross section

\begin{tabular}{|c|c|}
\hline \multicolumn{2}{|c|}{$\begin{array}{l}\text { SPECIFIC POLLUTANTS FROM TEXTILE AND } \\
\text { DYEING PROCESSING OPERATIONS [20] }\end{array}$} \\
\hline Process & Compounds \\
\hline Desizing & Sizes, ammonia, starch, enzymes, waxes \\
\hline Bleaching & $\begin{array}{l}\text { High pH, } \mathrm{AOX} \text {, sodium silicate or organic } \\
\text { stabiliser, } \mathrm{H}_{2} \mathrm{O}_{2}\end{array}$ \\
\hline Scouring & $\begin{array}{l}\mathrm{NaOH} \text {, disinfectants residues, surfactants, } \\
\text { waxes, fats, pectin, anti-static agents, oils, } \\
\text { spent solvents, soaps, enzymes }\end{array}$ \\
\hline Mercerizing & High $\mathrm{pH}, \mathrm{NaOH}$ \\
\hline Printing & Solvents, urea, metals, colour \\
\hline Dyeing & $\begin{array}{l}\text { Metals, colour, salts, organic processing } \\
\text { assistants, surfactants, sulphide, } \\
\text { formaldehyde, high/low } \mathrm{pH} \text {, }\end{array}$ \\
\hline Finishing & $\begin{array}{l}\text { Waxes, resins, acetate, chlorinated } \\
\text { compounds, spent solvents, stearate, } \\
\text { softeners }\end{array}$ \\
\hline
\end{tabular}

and color causing damage to the human health and environment. Typical characteristics of textile effluent are shown in table 2 [21].

As the wastewater is harmful to the environment and people, there are strict requirements for discharged influents. However, due to the difference in the raw

Table 2

TYPICAL CHARACTERISTICS OF TEXTILE EFFLUENTS [21]

\begin{tabular}{|c|c|}
\hline Parameter & Value \\
\hline $\mathrm{pH}$ & $6-10$ \\
\hline Total dissolved solids [mg/l] & $8.000-12.000$ \\
\hline $\mathrm{BOD}[\mathrm{mg} / \mathrm{l}]$ & $80-6.000$ \\
\hline COD [mg/l] & $150-12000$ \\
\hline Total suspended solids [mg/l] & $15-8.000$ \\
\hline Chlorine [mg/l] & $1.000-6.000$ \\
\hline $\mathrm{SO}_{4}[\mathrm{mg} / \mathrm{l}]$ & $600-1.000$ \\
\hline Total Kjeldahl Nitrogen [mg/l] & $70-80$ \\
\hline
\end{tabular}


THE LIMITS OF DISCHARGED CONCENTRATION IN DIFFERENT COUNTRIES [22-23]

\begin{tabular}{|l|r|r|r|r|r|r|}
\hline & & \multicolumn{3}{|c|}{ CHINA } & \multicolumn{2}{|c|}{ ROMANIA } \\
\cline { 3 - 8 } Parameter & GERMANY & $\begin{array}{c}\text { The limits of } \\
\text { discharged } \\
\text { concentration }\end{array}$ & $\begin{array}{c}\text { The limits of discharged } \\
\text { concentration for new } \\
\text { factory }\end{array}$ & $\begin{array}{c}\text { The special limits } \\
\text { of discharged } \\
\text { concentration }\end{array}$ & NTPA 002 & NTPA 001 \\
\hline $\mathrm{COD}[\mathrm{mg} / \mathrm{l}]$ & 160.0 & 100.0 & 80.0 & 60.0 & 500.0 & $70.0(125.0)$ \\
\hline $\mathrm{BOD}[\mathrm{mg} / \mathrm{l}]$ & 25.0 & 25.0 & 20.0 & 15.0 & 300.0 & $20.0(25.0)$ \\
\hline $\mathrm{TP}[\mathrm{mg} / \mathrm{l}]$ & 2.0 & 1.0 & 0.5 .0 & 0.5 & 5.0 & $1.0(2.0)$ \\
\hline $\mathrm{TN}[\mathrm{mg} / \mathrm{l}]$ & 20.0 & 20.0 & 15.0 & 12.0 & 30.0 & $10.0(15.0)$ \\
\hline $\mathrm{NH}_{3}-\mathrm{H}[\mathrm{mg} / \mathrm{l}]$ & 10.0 & 15.0 & 12.0 & 10.0 & $\mathrm{NA}$ & $\mathrm{NA}$ \\
\hline $\mathrm{TSS}[\mathrm{mg} / \mathrm{l}]$ & $\mathrm{NA}$ & 70.0 & 60.0 & 20.0 & 350.0 & $35.0(60.0)$ \\
\hline
\end{tabular}

materials, products, dyes, technology and equipment, the standards of the wastewater emission have many items. The standards of printing and dyeing vary from a country to another. Through access to the relevant information, the textile industry standards for water pollutants in Germany, China and Romania are presented. It is developed by the national environmental protection department according to the local conditions and environmental protection. In some countries such as China, the limits for the discharged pollutants are different depending on the factory situation. In other countries the limits vary depending on the region. Table 3 presents the maximum discharge limits for Germany, China and Romania [22-23].

\section{Recommended placement of MBBRs in textile wastewater treatment plants}

As the pollutant number is high several treatment stages can be combined for an efficient wastewater treatment. The main treatment stages for the textile wastewater treatment are: physicochemical treatment (equalization and homogenization; floatation; coagulation flocculation sedimentation; chemical oxidation; adsorption; membrane separation process), biological wastewater treatment (activated sludge process; oxidation ditch process; sequencing batch reactor activated sludge process; MBBR; rotating biological contactor), biochemical and physicochemical combination processes and advanced treatment stages (photochemical oxidation; electrochemical oxidation; ultrasonic technology; high energy physical process).

Based on the influent characteristics and all the available treatment process, a general diagram for the textile wastewater treatment (figure 8) is proposed by the authors. The MBBR technology is recommend to be used due to its advantages related to other biological treatment.

\section{CONCLUSIONS}

The textile industry, apart from being an important contributor to the economy of numerous countries, is also a major source of various liquid, solid and gaseous wastes. This kind of industrial activity has a

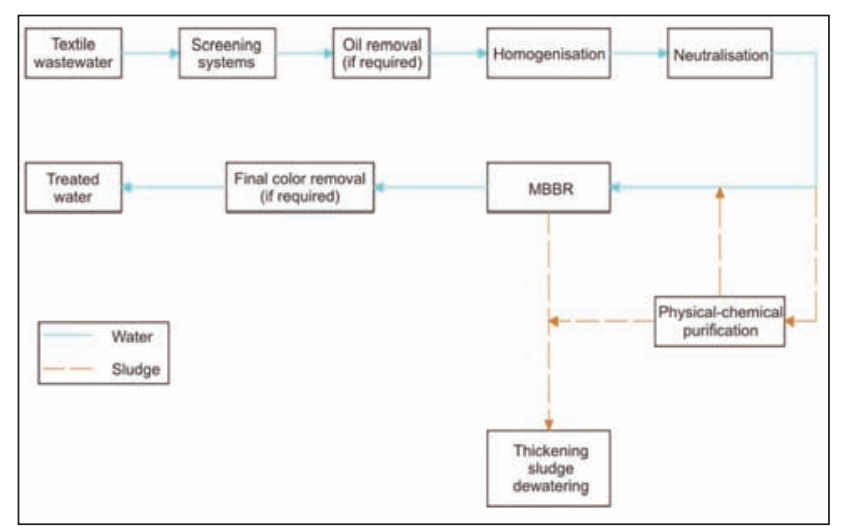

Fig. 8. The simplified diagram of wastewater treatment plant in the textile industry

negative impact on the environment, both in terms of pollutant discharge as well as of water and energy consumption.

In this context researchers are searching for new cost-effective treatment technologies. The authors recommend the MBBR utilization in textile wastewater treatment processes because it meets the requirements of an efficient and cost-effective technology. So far, wastewater treatment plants all over the world are using MBBR treatment stages but the researchers are actual and constantly are seeking ways to increase the efficiency. The researches more and more use new mathematical instruments for modelling and simulation. MBBR has proved the efficiency of reducing especially BOD and ammonia, in small tank volumes.

\section{AKNOLEDGEMENTS}

The authors would like to thank the EU and RCN (Norway), Federal Ministry of Food and Agriculture of Germany, Academy of Finland, Environmental Protection Agency of Ireland, Executive Agency for Higher Education, Research, Development and Innovation Funding of Romania, and Swedish Research Council for funding, in the frame of the collaborative international consortium (consortium acronym - ABAWARE) financed under the ERA-NET Cofund WaterWorks2015 Call. This ERA-NET is an integral part of the 2016 Joint Activities developed by the Water Challenges for a Changing World Joint Programme Initiative (Water JPI). 
[1] Metcalf and Eddy, Inc., Wastewater engineering: Treatment and reuse, fourth edition. McGraw-Hill Handbooks, New York, USA (2003).

[2] *** Environmental Protection Agency, 1994, available at: https://www.lexadin.nl/wlg/legis/nofr/oeur/arch/gha/490.pdf

[3] http://www.headworksinternational.com/biological-wastewater-treatment/MBBR.aspx.

[4] http://www.directindustry.com/prod/anoxkaldnes-ab/product-89321-919221.html.

[5] McDougald, D., Rice, S.A., Barraud, N., Steinberg, P.D., Kjelleberg, S. Should we stay or should we go: mechanisms and ecological consequences for biofilm dispersal, In: Nat. Rev. Microbiol., 2012, vol. 10, pp. 39-50.

[6] Marshall, K.C. Planctonic versus sessile life of Prokayotes in the prokaryotes-Prokayotic communities and ecophysiology, In: ed. Rosenberg E., Delong E.F., Lory S., Stackebrandt and Thmpson F., 2013, pp. 191-203.

[7] Moldoveanu, A.M., Ardelean, I.I. The formation of bacterial biofilms on the hidrofile surface of glass in laboratory static conditions: the effect of temperatura and salinity, In: Ovidius University Annals of Natural Sciences, Biology - EcologySeries, 2010a, vol. 14, pp. 147-156.

[8] Moldoveanu, A.M., Ardelean, I.I. Studies regarding the formation and temporal dynamics of bacterialbiofilms on the hydrophile surfaces of glass in static and dynamiccondition, In: Journal of Scienceand Arts, 2010b, vol.13, no 2, pp. 313-318.

[9] Costerton, J. W., The Biofilm Primer, Springer-Verlag Berlin Heidelberg, Germany, 2007.

[10] Madsen, E.L. Environmental microbiolgy, Blackwell Publishing, USA, 2008.

[11] Sehar, S., Naz, I. Role of the Biofilms in Wastewater Treatment, Microbial Biofilms - Importance and Applications, 2016 Dr. Dharumadurai Dhanasekaran (Ed.), In: Tech, DOI: 10.5772/63499. Available from: https://www. intechopen.com/books/microbial-biofilms-importance-and-applications/role-of-the-biofilms-in-wastewater-treatment.

[12] An, Y.H., Friedman, R.J. Laboratory methods for studies of bacterial adhesion. In: J. Microbiol. Methods, 1997, vol. 30, pp. 141-152.

[13] Pantanella, F., Valenti, P., Natalizi, T., Passeri, D., Berlutti, F. Analytical techniques to study microbial biofilm on abiotic surfaces: pros and cons of the main techniques currently in use, In: Ann Ig, 2013, vol. 25, pp. 31-42 doi:10.7416/ai.2013.1904.

[14] Strotmann, U.J., Butz, B., Bias, W. R. A dehydrogenase assay with resazurin-practical performance as a monitoringsystem and pH-dependent toxicity of phenolic-compounds, In: Ecotoxicol. Environ. Saf., 1993, vol. 25, pp. 79-89 doi:10.1006/eesa.1993.1009.

[15] Guerin, T.F., Mondido, M., McClenn, B., Peasley, B. Application of resazurin for estimating abundance of contaminant-degrading micro-organisms, In: Lett ApplMicrobiol, 2001, vol. 32, pp. 340-345.

[16] Peeters, E., Nelis, H.J., Coenye, T. Evaluation of the efficacy of disinfection procedures against Burkholderiacenocepacia biofilms, In: J Hosp Infect, 2008, vol. 70, pp 361-8.

[17] Mariscal, A., Lopez-Gigosos, R.M., Carnero-Varo, M., Fernandez-Crehuet. J. Fluorescent assay based on resazurin for detection of activity of disinfectants against bacterial biofilm, In: ApplMicrobiolBiotechnol, 2009, vol. 82, pp. 773-783.

[18] Iordan, M.C., Ardelean, I.I. Biological waste water treatment: 1. monitoring metabolic activity of activated sludge and the chemical parameters of waste water treatment, In: The International Conference of the University of Agronomic Sciences and Veterinary Medicine of Bucharest, Agriculture for Life, Life for Agriculture June 4-6, 2015, Bucharest, Romania, Series F. Biotechnologies, Vol. XIX ISSN 2285-1364, ISSN CD-ROM 2285-5521, ISSN ONLINE 22851372, ISSN-L 2285-1364.

[19] Iordan, M.C., Manea, R.G., Ardelean, I.I. Monitoring metabolic activity of activated sludge and the chemical parameters in laboratory activated sludge sequencing batch reactor, In: 16th International Multidisciplinary Scientific Geo Conference SGEM, 2016, www.sgem.org, SGEM 2016 Conference Proceedings, ISBN 978-619-7105-68-1 / ISSN 1314-2704, June 28-July 6, 2016, Book6 Nano, Bio and Green Technologies for a sustainable future Vol. 1, 653-660 pp, DOI: 10.5593/SGEM2016/B61/S25.086.

[20] All'egre, C., Moulin, P., Maisseu, M., Charbit, F. (2006). Treatment and reuse of reactive dyeing effluents. In: Journal of Membrane Science 269 (2006) pp. 15-34.

[21] Ghaly, A.E., Ananthashankar, R., Alhattab M., Ramakrishnan, V.V. Production, characterization and treatment of textile effluents: A critical review. In: Journal of Chemical Engineering \& Process Technology, 2014, vol. 5 available at: Chem Eng Process Technol 2014, 5:1.

[22] Zongping Wang, Miaomiao Xue, Kai Huang and Zizheng Liu (2011). Textile dyeing wastewater treatment, advances in treating textile effluent, prof. Peter Hauser (Ed.), ISBN: 978-953-307-704-8, InTech, pp. 91-116, available from: http://www.intechopen.com/books/advances-in-treating-textile-effluent/textile-dyeing-wastewatertreatment.

[23] http://www.gnm.ro/otherdocs/nsbhrtjqp.pdf.

\section{Authors:}

IOANA CORINA MOGA ${ }^{1}$, IOAN ARDELEAN ${ }^{2}$, GABRIEL PETRESCU ${ }^{1}$, NICOLAE CRĂCIUN ${ }^{3}$, RADU POPA 3 , 4

${ }^{1}$ Department of Research and Development, DFR Systems SRL, Bucharest, Romania

${ }^{2}$ Institute of Biology Bucharest, Romanian Academy, Bucharest, Romania

${ }^{3}$ Research Department, Aquaterra, Bucharest, Romania

${ }^{4}$ University of Southern California, Los Angeles, USA

Corresponding author:

IOANA CORINA MOGA

e-mail: corinamoga@yahoo.com 